\title{
Agresivitas Mahasiswa UIN Maulana Malik Ibrahim Malang
}

\author{
M. Nawa Syarif Fajar Sakti \\ Pascasarjana UIN Maulana Malik Ibrahim Malang \\ nawasyarif.ns@gmail.com \\ Ahmad Anton Fatoni \\ Pascasarjana UIN Maulana Malik Ibrahim Malang \\ Ayu Ernawati \\ Pascasarjana UIN Maulana Malik Ibrahim Malang \\ Ulfatus Zakiyah \\ Pascasarjana UIN Maulana Malik Ibrahim Malang
}

\begin{abstract}
Aggression is often interpreted as a behavior that aims to hurt others both physically and verbally. This study uses a quantitative approach, the research technique used is a correlational technique that is a research model that intends to conduct research and assessment of the characteristics of a population through samples drawn from that population. Based on the findings of the researchers, spiritual intelligence has a positive and significant effect on the Aggressiveness of Students of Malang's Maulana Malik Ibrahim UIN which is indicated by a significance value of less than the level of significant ie 0.050 or $(0,000<0.050)$ that the influence of spiritual intelligence on students' aggressive and significant, thus the higher the spiritual intelligence, the lower the aggressiveness of the UIN Student Maulana Malik Ibrahim
\end{abstract}

Keywords: spiritual intelligence; aggressiveness; students

\begin{abstract}
Abstrak
Agresi sering diartikan sebagai suatu perilaku yang bertujuan untuk menyakiti orang lain baik secara fisik maupun verbal. Penelitian ini menggunakan pendekatan kuantitatif, teknik penelitian yang digunakan adalah teknik korelasional yaitu suatu model penelitian yang bermaksud mengadakan penelitian dan penaksiran tentang karakteristik suatu populasi melalui sampel yang ditarik dari populasi tersebut. Berdasarkan temuan peneliti, kecerdasan spiritual berpengaruh positif dan signifikan terhadap Agresivitas Mahasiswa UIN Maulana Malik Ibrahim Malang yang ditunjukkan dengan nilai signifikansi kurang dari level of significant yaitu 0,050 atau $(0,000<0,050)$ bahwa pengaruh Kecerdasan spiritual terhadap agresivitas Mahasiswa UIN Maulana Malik Ibrahim bersifat
\end{abstract}


positif dan signifikan, dengan demikian semakin tinggi Kecerdasan spiritual maka akan semakin rendah agresivitas Mahasiswa UIN Maulana Malik Ibrahim.

Kata Kunci: kecerdasan spiritual; agresivitas; mahasiswa

\section{Pendahuluan}

Perkembangan informasi yang pesat pada era globalisasi saat ini memberikan peluang bagi remaja untuk terlibat secara langsung dalam suasana kehidupan global. Laju perkembangan arus informasi dan teknologi secara bersamaan memberikan pengaruh pada perkembangan remaja. Tahap perkembangan remaja yang masih mencari identitas diri dan perubahan-perubahan yang terjdi menjelang masa remaja seperti perubahan fisik, emosi dan kehidupan sosial membuat remaja dihadapkan pada berbagai alternatif pilihan yang tersedia di tengah lingkungan.

Pergolakan emosi yang terjadi pada remaja tidak terlepas dari bermacammacam pengaruh seperti lingkungan tempat tinggal, keluarga, sekolah dan teman sebaya serta aktivitas aktivitas yang dilakukannya dalam kehidupan sehari-hari. Masa remaja dapat dikenal sebagai masa strum and drag atau storm and stress, masa yang penuh dengan konflik dan ketidakpastian, karena pada masa ini remaja mengalami banyak perubahan antara lain perubahan pada emosi, perubahan pada fisik atau tubuh serta perubahan pada pola perilaku, minat dan nilai yang ada pada dirinya (Hurlock,1993).

Agresi sering diartikan sebagai suatu perilaku yang bertujuan untuk menyakiti orang lain baik secara fisik maupun verbal. Berkowitz (2003) mendefinisikan agresi sebagai segala bentuk perilaku yang dimaksudkan untuk menyakiti orang lain secara fisik maupun mental. Pendapat lain menyatakan bahwa menyakiti bukan satu-satunya tujuan, karena agresi dapat juga bertujuan untuk melindungi diri sendiri untuk menunjukkan patriotisme ataupun alat untuk mendapatkan dukungan sosial.

Buss and Perry (1992) mengatakan bahwa agresi adalah keinginan untuk menyakiti orang lain, mengekspresikan perasaan sifat negatifnya seperti permusuhan dalam rangka mencapai tujuan yang diinginkan. Ia mengatakan juga 
bahwa ada empat aspek pada agresi, yaitu agresi fisik, agresi verbal, kemarahan (anger), dan kebencian (hostility) (Praditya dkk, 1999)

1. Agresi fisik adalah agresi yang dilakukan untuk melukai orang lain secara fisik, seperti memukul, menendang, menusuk, membakar, dan sebagainya.

2.

Agresi verbal yaitu kecenderungan untuk menyerang orang lain secara verbal, seperti cacian, ancaman, mengumpat, membentak atau sebuah penolakan

3.

Kemarahan (Anger): beberapa bentuk kemarahan yaitu perasaan marah, kesal, atau pun sebal. Kemarahan merupakan perasaan tidak senang sebagai reaksi atas cedera fisik maupun psikis yang diderita individu (Amriel, 1997).

Sikap permusuhan yang meliputi komponen kognitif, seperti benci dan curiga pada orang lain, iri hati dan merasa tidak adil dalam kehidupan. Contohnya, seseorang sering merasa curiga terhadap orang lain, yang dikiranya menaruh dendam pada dirinya, padahal orang lain tersebut tidak dendam terhadapnya.

Tokoh lain seperti Baron dan Byrne (1997) menerangkan, penyebab dasar perilaku agresi dikelompokkan menjadi tiga pendekatan: pendekatan biologis, pendekatan eksternal dan pendekatan belajar.

Peristiwa yang terjadi pada akhir-akhir ini sangatlah memprihatinkan, karena kecenderungan merosotnya moral bangsa hampir terasa di semua strata kehidupan. Khusus di kalangan mahasiswa, Gejolak emosi remaja pada mahasiswa yang menggebu-gebu membuat emosi dalam diri tidak terkontrol. Hal itu sering berdampak dan berujung pada kekerasan atau tawuran. Amarah atau emosi yang tidak terkontrol yang timbul secara alami dari balam diri remaja itulah faktor terbesar munculnya agresi atau berontak dari dalam diri masing-masing remaja. problema sosial moral ini dicirikan dengan sikap arogansi, saling memfitnah sesama teman, rendahnya kepeduliaan sosial, meningkatnya hubungan seks pra-nikah, bahkan merosotnya penghargaan dan rasa hormat terhadap orang tua dan dosen sebagai sosok yang seharusnya disegani dan dihormati. 
Mahasiswa Universitas Islam Negeri Malang adalah peserta didik yang diharapkan tampil sebagai calon pemimpin umat sebagai indikatornya adalah keagungan akhlak, keluasan ilmu pengetahuan, kedalaman spiritual dan kematangan profesi. Dalam kenyataannya pada peristiwa 29 April 2019 terdapat keributan di daerah kampus UIN Malang, para mahasiswa melaksanakan aksi demonstrasi terhadap mahalnya biaya pendidikan UIN Malang dengan cara memutari wilayah kampus berbondong-bondong membawa spanduk yang bertuliskan kata-kata tercela serta melakukan orasi yang provokatif sehingga mengganggu aktivitas civitas akademika kampus UIN Malang. (beritajatim.com, 29 April 2019).

Hasil pengamatan penulis didukung oleh Kurniasari dan S Padmomartono meneliti Pengaruh Kecerdasan Emosional Terhadap Agresivitas Siswa Kelas VIII SMP Negeri 1 Sumowono. Hasil analisis regresi diperoleh nilai $F=120.580$ dengan koefisien regresi kecerdasan emosional terhadap agresivitas siswa sebesar - 0,625 dan Sig = 0,000<0,05, dan diperoleh $R$ Square atau koefisien determinasi menunjukkan sebagian besar pengaruh model regresi yang dibentuk oleh variabel bebas dan variabel terikat sebesar $62,5 \%$. Disimpulkan variabel bebas kecerdasan emosional memiliki kontribusi sebesar $62,5 \%$ terhadap variabel terikat agresivitas, sedangkan $37,5 \%$ dipengaruhi oleh faktor- faktor lainnya di luar variabel kecerdasan emosional. Dari tabel tersebut juga nampak Sig $=0,00$ berarti pengaruh kecerdasan emosional terhadap agresivitas adalah sangat signifikan.

Sebagai suatu ajaran, Islam bagi umat manusia sangat menekankan tentang betapa pentingnya seseorang itu menjadi cerdas baik secara intelektual, emosional maupun spiritual. Terdapat banyak ayat Al-Quran yang menganjurkan kepada umat manusia untuk selalu menggunakan akal, emosi (hati), dan spiritualnya. Sebaliknya Islam sangat melarang pada umatnya untuk berbuat keji pada orang lain, salah satu perbuatan keji yang dilarang adalah menyakiti orang lain baik secara lisan maupun fisik, baik secara langsung maupun tak langsung. Terlebih bagi kampus yang menyandang nama Islam harusnya memiliki nilai lebih dalam mencerminkan nilai-nilai keislaman pada aspek spiritual. 
Kecerdasan spiritual (SQ) adalah kecerdasan untuk menghadapi dan memecahkan persoalan makna kehidupan, nilai-nilai, dan keutuhan diri yaitu kecerdasan untuk menempatkan perilaku dan hidup kita dalam konteks makna yang lebih luas dan kaya, kecerdasan untuk menilai bahwa tindakan atau jalan hidup seseorang lebih bermakna dibandingkan dengan yang lain. Seseorang dapat menemukan makna hidup dari bekerja, belajar dan bertanya, bahkan saat menghadapi masalah atau penderitaan. Kecerdasan spiritual merupakan kecerdasan jiwa yang membantu menyembuhkan dan membangun diri manusia secara utuh. Kecerdasan spiritual adalah landasan yang diperlukan untuk memfungsikan IQ dan EQ secara efektif. Bahkan, SQ merupakan kecerdasan tertinggi (Zohar dan Marshall: 2001)menyatakan bahwa kecerdasan spiritual memungkinkan seseorang untuk mengenali nilai sifat-sifat pada orang lain serta dalam dirinya sendiri.

Kecerdasan spiritual dibangun atas teori "God Spot” (Titik Tuhan) yang dipelopori oleh Terence Deacon dan Viktor Frankl pada akhir 1990. God spot merupakan sekumpulan saraf yang terletak di daerah lobus temporal otak dibalik pelipis. God spot berfungsi menyadarkan akan eksistensi fundamental yang menyebabkan kita bersikap idealistis dan mencari solusi atas problem yang ada. God spot membuat kita berhasrat pada sesuatu yang lebih tinggi (transenden), sehingga muncul rasa cinta yang mendalam, rasa damai yang mendalam, rasa kesatuan eksistensi, dan keindahan yang mendalam (Zohar dan Marshal, 2004).

Seiring dengan berkembangnya waktu dewasa ini teori Godspot diterjemahkan dalam konsep yang dikenal dengan kecerdasan spiritual. Kecerdasan spiritual terdiri dari gabungan kecerdasan dan spiritual. Kecerdasan berasal dari kata cerdas yaitu sempurna perkembangan akal budi untuk berpikir dan mengerti (Departemen Pendidikan, 2002). Sedangkan spiritual berasal dari kata spirit yang berasal dari bahasa latin yaitu spiritus yang bearti nafas. Dalam istilah modern mengacu kepada energi batin yang non jasmani meliputi emosi dan karakter (Buzan, 2003).

Menurut Donah Zohar dan Ian Marshal mendefinisikan, kecerdasan spiritual adalah kecerdasan untuk menghadapi dan memecahkan persoalan hidup, 
makna dan nilai, yaitu kecerdasan untuk menempatkan prilaku dan hidup manusia dalam kontek makna yang luas dan kaya, kecerdasan untuk menilai bahwa tindakan atau jalan hidup seseorang lebih bermakna dibandingkan dengan yang lain (Zohar dan Marshal, 2004). Kecerdasan spiritual merupakan kecerdasan yang bertumpu pada nilai-nilai insaniah kemanusiaan sehingga ia mampu untuk memberi makna ibadah terhadap setiap perilaku dan kegiatan, melalui langkahlangkah dan pemikiran yang bersifat fitrah,menuju manusia seutuhnya (hanif), dan memiliki pola pemikiran tauhidi (integralistik) serta berprinsip "hanya karena Allah" (Agustian, 2001).

Hasil pengamatan penulis didukung oleh Aziz dan Mangestuti (2012) meneliti pengaruh Kecerdasan Intelektual (IQ), Kecerdasan Emosional (EI) dan Kecerdasan Spiritual (SI) terhadap Agresivitas Mahasiswa UIN Malang dengan hasil nilai $R$ Square diperoleh skor 0.325 artinya kecerdasan intelektual, kecerdasan emosional, dan kecerdasan spiritual secara bersamasama mampu mempengaruhi agresivitas mahasiswa sebesar 32,5\%, masih sekitar 67,5\% faktor lain yang mempengaruhi agresivitas mahasiswa. Faktor tersebut bisa berupa faktor yang berasal dari dalam diri atau faktor yang berasal dari luar diri mahasiswa.

Sabiq dan Djalali (2012) yang melakukan penelitian dengan judul Kecerderdasan Emosi, Kecerdasan Spiritual dan Perilaku Prososial Santri Pondok Pesantren Nasyrul Ulum Pamekasan. Hasil analisis regresi diperoleh nilai F sebesar 105,406 dengan harga $\mathrm{p}=0,000(\mathrm{p}<0,05)$ yang berarti bahwa kecerdasan emosi dan kecerdasan spiritual mempunyai hubungan yang signifikan dengan perilaku prososial. dan diperoleh $R$ Square dengan skor 0,551 yang memberikan informasi bahwa kedua variabel bebas kecerdasan emosi dan kecerdasan spiritual secara bersama-sama memberikan sumbangan efektif terhadap variabel tergantung perilaku prososial sebesar 55,1 \%. Hal ini berarti terdapat $44,9 \%$ variabelvariabel lain yang mempengaruhi variabel tergantung perilaku prososial dalam penelitian ini.

Pada penelitian ini, kecerdasan spiritual diduga dapat dijadikan sebagai prediktor bagi tinggi rendahnya perilaku agresif pada mahasiswa UIN Maulana 
Malik Ibrahim Malang. Sehingga hipotesis yang diajukan diuji seberapa besar pengaruhnya terhadap agresivitas mahasiswa.

\section{METODE}

Penelitian ini menggunakan pendekatan kuantitatif yaitu penelitian berupa angka-angka dan analisis menggunakan statistik. Teknik penelitian yang digunakan adalah teknik korelasional yaitu suatu model penelitian yang bermaksud mengadakan penelitian dan penaksiran tentang karakteristik suatu populasi melalui sampel yang ditarik dari populasi tersebut. Teknik korelasional ini bertujuan untuk mengetahui hubungan antara kecerdasan emosional dengan perilaku agresif.

Definisi Operasional:

Untuk menghindari kesalah pahaman maka dalam penelitian ini diberikan definisi operasional sebagai berikut:

a. Agresivitas adalah suatu perilaku, kecenderungan atau stimulus yang tidak menyenangkan atau merugikan, baik perilaku fisik maupun verbal, yang dilakukan satu pihak kepada pihak lainnya dengan maksud menyakiti baik secara fisik maupun psikologis, dan dengan harapan bahwa perilaku atau tindakan tersebut akan mencapai hasil yang diinginkan atau mempunyai tujuan.

b. Kecerdasan spiritual merupakan kemampuan yang sempurna dari perkembangan akal budi untuk memikirkan hal-hal di luar alam materi yang bersifat ketuhanan yang memancarkan energi batin untuk memotivasi lahirnya ibadah dan moral.

Populasi dan Sampel:

Populasi, menurut Hadi (1996) adalah semua individu yang termasuk dalam kriteria-kriteria sample yang ditentukan, sedangkan menurut Nadzir (1987), pengertian populasi yaitu kumpulan dari individu dengan kualitas serta ciri-ciri yang telah ditetapkan. Populasi dalam penelitian ini adalah semua mahasiswa yang Universitas Islam Negeri Malang. 
Teknik pengambilan sampel yang digunakan dalam penelitian ini adalah proportional random sampling yaitu memilih individu-individu yang ada dikelaskelas perkuliahan dari tiap-tiap fakultas secara random.

Alat Ukur:

1. Skala Agresivitas

Alat ini berupa skala psikologis sebanyak 18 item yang mampu mengungkap tingkat agresivitas. Skala ini disusun dengan merujuk pada Buss, A.H., \& Perry, M. (1992). The Aggression Questionnaire. Journal of Personality and Social Psychology dengan beberapa aspek diantaranya kemarahan, verbal agression, hostility, dan physical agression.

2. Skala Spiritual

Alat ini berupa skala psikologis sebanyak 18 item yang mampu mengungkap tingkat agresivitas. Skala ini disusun dengan merujuk pada Danah Zohar dan Ian Marshall, SQ: Kecerdasan Spiritual, (2007) dengan beberapa aspek diantaranya

a. Memiliki tingkat kesadaran yang tinggi

b. Berkaitan dengan keimanan

c. Memiliki rasa tanggung jawab dan keengganan untuk menyebabkan kerugian yang tidak perlu

d. Kemampuan untuk menghadapi dan memanfaatkan penderitaan

e. Berdzikir dan berdoa

Bentuk skala yang digunakan adalah skala pengukuran Likert, dimana sebagai dasar penentuan nilainya dikategorikan dalam item Favorable sangat setuju (4), setuju (3), tidak setuju (2), sangat tidak setuju (1), dan item Unfavorable sangat setuju (1), setuju (2), tidak setuju (3), sangat tidak setuju (4).

\section{Hasil dan Pembahasan}

Hasil uji regresi sederhana

Analisis regresi linier sederhana digunakan untuk mengetahui pengaruh variabel independen secara individu terhadap variabel dependen. Hasil uji regresi linier sederhana variable independen yang terdiri dari Kecerdasan Spiritual secara individu terhadap agresivitas mahasiswa adalah sebagai berikut: 
Tabel 1 Hasil Uji Regresi

\begin{tabular}{llll}
\hline Model & R Square & Beta & Sig \\
\hline (Constant) & & & .000 \\
\hline Spiritual & .206 & -.454 & .000 \\
\hline Dependent & Variable: & Agresivitas
\end{tabular}

Dari output dapat dilihat bahwa variabel independen yang dimasukkan ke dalam model adalah kecerdasan spiritual dan variabel dependennya adalah Agresivitas dan tidak ada variabel yang dikeluarkan. Sedangkan metode regresi menggunakan Enter, dengan hasil sebagai berikut:

1. $\mathrm{R}$ dalam analisis regresi linear sederhana menunjukkan korelasi sederhana (korelasi Pearson) yaitu korelasi antara satu variabel independen terahadap satu variabel dependen . Angka $\mathrm{R}=454$ sehingga kecerdasan spiritual berpengaruh negative terhadap agresivitas.

2. R Square, nilai $\mathrm{R}$ square dengan koefisien determinan 206. Artinya agresivitas dipengaruhi oleh keceredasan spiritual sebesar 20,6\%. Dan sisanya dipengaruhi oleh variabel lain yang tidak dimasukkan dalam model ini.

3. Signifikansi, adalah probabilitas atau peluang untuk memperoleh kesalahan dalam mengambil keputusan. Jika pengujia menggunakan tingkat signifikansi 000, maka peluang memperoleh kesalahan maksimal $0 \%$

Penelitian yang dilakukan Aziz (2006) pada mahasiswa UIN Maulana Malik Ibrahim Malang, dalam jurnalnya menjelaskan pengaruh kecerdasan spiritual terhadap agresivitas mempunyai korelasi sebesar - .548 dengan nilai $\mathrm{P}=.000$. Hal ini menunjukkan penurunan terhadap tingkat pengaruh kematangan spiritual terhadap agresivitas mahasiswa UIN Malang. Bahwa kecerdasan spiritual lebih berhubungan dengan sesuatu yang bersifat transenden dan pemaknaan terhadap suatu perilaku. Karena itu bisa dipahami kalau orang yang tingkat kecerdasan spiritualnya tinggi maka ia mengembalikan segala perbuatannya kepada Tuhannya sehingga perbuatannya menjadi bermakna dalam hidupnya. 


\section{Kesimpulan}

Kecerdasan spiritual berpengaruh positif dan signifikan terhadap Agresivitas Mahasiswa UIN Maulana Malik Ibrahim Malang yang ditunjukkan dengan nilai signifikansi kurang dari level of significant yaitu 0,050 atau $(0,000<$ 0,050). Hal ini menunjukkan bahwa pengaruh Kecerdasan spiritual terhadap agresivitas Mahasiswa UIN Maulana Malik Ibrahim bersifat positif dan signifikan, dengan demikian semakin tinggi Kecerdasan spiritual maka akan semakin rendah agresivitas Mahasiswa UIN Maulana Malik Ibrahim.

\section{DAFTAR PUSTAKA}

Agustian, A.G. 2001. Rahasia Sukses Membangun Kecerdasan Emosidan Spiritual ESQ Emotional Spiritual Quotient. Jakarta: Arga.

Aziz, R., Mangestuti, Retno. 2006. Pengaruh Kecerdasan Intelektual, Kecerdasan Emosional Dan Kecerdasan Spiritual Terhadap Agresivitas Pada Mahasiswa Uin Malang. El-Qudwah, Jurnal Penelitian dan Pengembangan.

Berkowitz, A. 2003. Applications of social norms theory to other health and social justice issues. Chapter 16 in $\mathrm{H}$. W. Perkins (Ed.). The social norms approach to preventing school and college age substance abuse: A handbook for educators, counselors, clinicians. San Francisco: JosseyBass.

Berkowitz, A. D. 2003. The social norms approach: Theory, research and annotated bibliography. Higher Education Center for Alcohol and Other Drug Prevention, www.edc.org/hec/socialnorms/

Berkowitz, L. 2003. Emosional Behavior: Mengenali perilaku dan tindakan kekerasan di lingkungan sekitar kita dan cara penanggulangannya. Penerjemah: Hartatni Woro Susiatni. Jakarta: CV. Teruna Grafica.

Berkowitz, L. 2005. Agresi: Sebab \& Akibatnya. Jakarta: PT Pustaka Binaman Pressindo.

Berkowitz, L. 2006. Emotional Behavior. Jakarta: Penerbit PPM

Buss, A.H \& Perry, M. 1992. The Aggression Questionnaire.Journal of Personality and Social Psychology. The American Psychological Association, Inc. 
Buzan, T. 2003. Kekuatan ESQ: 10 Langkah Meningkatkan Kecerdasan Emosional Spiritual, Terj. Ana Budi Kuswandani, cet 1. Jakarta: Pustaka Delapratohsa.

Departemen Pendidikan. 2002. Kamus Lengkap Besar Bahasa Indonesia. Jakarta: Balai Pustaka.

Hadi, S., 1996, Metodologi Research, (Jilid 3), Yogyakarta: Andi Offset

Hurlock,E.B.1993. Psikologi Perkembangan: Suatu pendekatan sepanjang rentang kehidupan (edisi kelima). Jakarta: Erlangga

James E., A,1984.Public Policy Making, New York, Holt, Rinehart and Wiston.

Mednick. S.A. H., Kirschenbaum. 1975. Exoloration in Behavior and ExperiencePsycholoqy New York: John Wiley and Sons.

Munasti, C. 2017. "Hubungan Antara Kecerdasan Spiritual dengan Tingkat Kesopanan Siswa di SMP Negeri 6 Banda Aceh. Skripsi. Banda Aceh: UIN Ar-Raniry Darussalam.

Nazir. M., 1987, Metode Penelitian, Jakarta: Ghalia Indonesia

Rudyanto, E. 2010. Hubungan Antara Kecerdasan Emosi dan Kecerdasan Spiritual dengan Prilaku Prososial Pada Perawat. Surakarta: Fakultas Kedoktoran.

Tasmara, T. 2001. Kecerdasan Ruhiah (Transdental Intelegensi: Membentuk Kepribadian yang Bertanggung Jawab, Professional dan Berakhlak). Jakarta: Gema Insani Press.

Zohar, D., Marshal, I. 2004. Spritual Capital: Memberdayakan SQ di Dunia Bisnis, Bandung: Mizan Pustaka. 